\title{
地域医療の中での薬剤師：駆け出しの医師から見て
}

\author{
江角浩安
}

\section{Role of Pharmacist in Comprehensive Community System: An Elder Beginner Medical Doctor's View}

\author{
Koan Esumi \\ Shima City Hospital; 1941-1 Nakiri, Daio-cho, Shima, Mie 517-0603, Japan.
}

(Received August 2, 2019)

\begin{abstract}
Pharmacists at National Cancer Center Hospital East play important roles in designing, conducting new protocol for clinical trials for developing new regimens and even new drugs. They are also key staffs in treating cancer patients in both in- and out-patient clinics by conducting chemotherapy and monitoring adverse effects. In addition, they educate patients and families before and during treatment by operating independent pharmacists' out-patient clinics. Pharmacists are in front-line of cancer chemotherapy. I was in National Cancer Center but am now in a small city hospital where most of the patients are age over 70 or 80 and frequently live alone. They are suffered from cancer, cardiovascular diseases, and mental diseases. Because most of the patients are elderly, their renal function is more or less disturbed. In this area, medical social workers, nurses, care workers and medical doctors together with visiting nurse system, care worker station try to let the patients enjoy life out of hospital. Japan is a leading country to overcome many problems in an elderly society and try to establish comprehensive community system. The position of pharmacists in this system is not fully clear in our city and probably in other city. Here is another frontier for pharmacists.
\end{abstract}

Key words_— patient-centered medicine; family medicine; new drug development

疾患のメカニズムは分子レベルでの理解が進み, がんの分子標的薬を典型に多くの新しい薬物の臨床 開発が進んでいる. 国立がん研究センター東病院で は，薬剤師はその薬学の専門知識を生かし治療プロ トコールの立案, 臨床試験の遂行, 管理, さらに結 果の解析まで中心メンバーとしての役割を果たして いる. 外来・入院化学療法は免疫療法が大幅に導入 され，従来とは異なった作用を示す薬剤が投与され るようになった。分子標的薬剤の導入時もそうで あったように，新しいカテゴリーの薬物の導入では 従来では予想もしなかつたような効果と場合によっ ては副作用が現れることがある。がん治療に限ら ず，多くの疾患で免疫学の進歩に基づいた治療薬が 広く導入されている現在は，かつては考えられない ほどの免疫学に関する理解，特に臨床免疫学の知識

国民健康保険志摩市民病院（广517-0603 三重県志摩市 大王町波切 1941-1)

e-mail: hesumi@ncc.go.jp

本総説は, 日本薬学会第 139 年会シンポジウム S42 で 発表した内容を中心に記述したものである.
が要求されている．新薬の臨床導入と，さらに実臨 床への導入は多くの場面で注意深い患者の観察を要 求される.これらの臨床導入において薬剤師はその 遂行，管理，副作用モニターなどで大きな柱として 働いている. 一方, 国立がん研究センター東病院で は 7-8 年前から薬剤師独自の外来を持ち, 専門的知 識を生かして患者に接し第一線での役割を果たし, まさに先端的がん医療の抜刀隊としての役割を演じ ている.

薬剤師は医師主導治験の中では薬学の専門家とし て, 薬事法に係わる知識も大いに期待されている. 膨大な申請書類を作り上げるためには原資料の正確 性がとても大切である。一般的な実臨床とは異なる プロトコールに従つた臨床試験の遂行は厳密な記録 の保存と言う, 通常とは少し異なつた注意力も必要 とされる.この中でも, 薬剤師の大きな役割があり 現に国立がん研究センター東病院ではこれを担って いる.

薬学者の新しい医療技術, 薬物, 機器の開発にお ける役割は，このようなやや臨床寄りのものに限ら 
ず基礎的な領域でも大きいものがあることはもちろ んのことだが，本稿では触れない，新薬の開発につ ながる基礎科学は, 遺伝学, 生物学, 分子生物学, 免疫学, 生化学と学部を超えて進められているが, ひとたび体に投与する化学物質という観点からする と, 薬学の独自領域は他の学部にはないものであり 今後もその専門性はおおいに大切にされるものと考 えられる。新薬の開発や，臨床導入，先端的医療現 場での薬剤師の役割は今までになかったほどに重要 性を増し, 患者に直接接する領域を広げつつ多様性 を獲得しつつある。

筆者は，三重県志摩市の常勤医 3 名，60 床の療 養及び地域包括ケア病床を持つ市民病院に勤めてい る. 以前に筆者が所属していた国立がん研究セン ターとは少し様相が異なる。まず患者の年齢であ る、がんは高齢者に多い疾患であり，国立がんセン ター東病院でも患者の平均年齢は 60 代後半で，ま るで高齢者の病院であるとよく話していた。 入院患 者の多い肺がん，胃がん，大腸がん，肝臓がんなど が 60 代や 70 代に多いがんであれば当然のことだ.

さらに, 社会の高齢化が進みもつと高齢のがん患者 も多く, おそらく医療技術の進歩と，お元気な高齢 者が増えたことも入院患者の高齢化の要因であろう と思われる。ところが志摩市民病院の患者は 60 代 は稀で，ほとんごが $70 ， 80 ， 90$ 代である．10\%ぐ らいの方は意識障害で言葉のコミュニケーションは できない，別の $10 \%$ では多少の応答はあるが意思 疎通は相当に手強く，さらに別の $10 \%$ は言語明朗 にして意味不明である。ときに気ままにお出かけの 方や一日中捜し物の方もいる，やたらに徘䧃する患 者から，実習に来ていた医学部の学生が聞き出し た。ご両親のお墓が近くにあるけれど最近墓参りを していないと言うことを，学生と理学療法士や看護 師が協力をしてご両親のお墓にお参りに連れていく と，その後すっかり落ち着いた症例がある．認知症 であるとかたづけないで丁寧な診療をすれば思いも かけない回答が得られることもある.

先日，まだ 70 代の糖尿病の患者でインスリンに よりうまく血糖コントロールできないために教育入 院となった. 入院し自己注射の教育をしてもなかな かうまくいかず，担当医は困難を感じていた，研修 中の医学生にこの患者の学生ができる範囲での担当 を任せた。学生が最初に発見したことは，この患者
はめがねが合ってないために自己注射の説明書や目 盛りが見えないことだった。がねを合わせてこの 学生は次の発見をした。この患者は漢字が読めない ことである，立派な説明書を，ややたどたどしいひ らがなとカタカナの説明書に書き換えた。この患者 は今は外来に元気で通院中である。現場には，思い もしない発見がある。どんなに立派で完璧な説明書 も何の意味もない場合がある。どんなに素晴らしい ぜんそくのスプレーも患者に指の力がなければ人を 助けることはできない．現場で初めてわかることは たくさんあるようだ.

志摩市民病院の入院患者は，がんや難病の終末期 や，転倒して骨折をした高齢者の術後のリハビリ テーション, 突然食欲がなくなった独居の高齢者, 脳出血や梗塞の後遺症のリハビリ中, 慢性重症腎不 全で透析のために外来通院の難しいひとなどが大部 分である.よくよく話を聞くと多くの方が本当は家 に帰りたいと言われる，兄弟も家族も近くには住ん でいない人でも，日常生活を自分でできなくても， 希望があれば訪問看護，介護，デイケア，訪問リハ ビリなどが全面的に協力し合いできる限り家に帰そ うと努力をしている，われわれは，人は病院や施設 で暮らすために生まれたとは考えないからであり， また多くの人がそれを希望しないからである．難し いことはたくさんにある.リアス式海岸の漁村であ れば，多くの家が急峻な坂の上や途中に建ってい る。道は狭く複雑で大きな車は入っていけない，そ の場合でも, 少しでも病院外の生活を楽しむため, 介護士，看護師，リハビリ，ソーシャルワーカー， 医師などが訪問看護，介護施設と緊密にタグを組み 少しでも希望を叶えようとしている．地域包括ケア システムなるものが導入されたが，地域によって ニーズは相当に異なる．筆者は，2030 年あたりで 日本のがん医療が破綻する可能性があることに今か ら 15 年前ぐらいにやっと気づき，国立がんセン ター東病院で地域医療，在宅療養を巻き込んだ医療 体制のモデルづくりを試みた，少し遅れて東京大学 とUR の柏プロジェクトが始まり大いに気を強くし たものである。その頃交流があった医師会や在宅医 療の先駆的運動をしている方たちから得た知識は, しかしこの志摩市民病院に来て，この場所の現実と はかなりかけ離れていると思った。医療資源の現 実，社会資源の現実，何よりも患者を取り巻く家族 
の現実が東京近郊や，多くのやや大きめの都市周辺 とは異なるようだ。その意味で，地域包括ケアシス テムはこれからその場その場で現実に合わせながら 作り上げるものであろうと思う。そのために多くの 医療関係者，介護関係者が緊密な連携を作り上げつ つある。

薬剂師の役割はこの中でなんだろうか？どのよ うに次の時代の医療・介護体制に責務を果たすの か? そのための学部教育は行われているのだろう か? 卒後教育はどうだろう? だいいち一体何を 教えようとしているだろうか?

地域医療の中の薬剤師は, 病院薬剤師, 調剂薬 局, 訪問薬剂師が思い浮かぶが単にポリファーマ シーだけが問題ではないようだ，テレビではよく， 高齢者の家には飲んでいない薬がこんなにありま す。その薬剤費は何百億円になります，などという どうでもいいことを言っている，全体の年間の薬剤 費にとってそれが 300 億であろうが 500 億であろう が数\%にも満たない．野菜を買ってきて食べること をイメージすれば数\%のロスなら少ない方である. もつと本質的なことを訴えるべきであり低俗な論理 は低俗な結論しか生み出さない。さて地域では OTCにも果たすことのできる大きな役目があるの
ではないだろうか？つたない経験から言えば，多 職種連携と呼ばれるチーム活動ではうまく専門性を 捨てることができたときに初めてうまくいくような 気がする。できあがった薬剤師や薬学者も地域医療 の現実を見てほしいが，いつそのこと若い学生や卒 後教育の早い段階で地域医療の現場で自分は何がで きるのかを自ら見つけ出させるのも教育の方法であ るように思う，現に，志摩市民病院では，常勤医が 3 人しかいないながらも多くの, 医学生の研修, 看 護学生, 理学療法士の学生, 果ては高校生や中学生 の研修実習を受け入れている，医療現場では微妙な 問題がたくさんあるが，これらの学生たちに受け持 ち患者を持たせ，医療行為以外の多くの自由を与え 同意を得た患者と直接接することを許している。こ の中で, 実に多くの学生たちが医師や看護師の気づ かなかったことを発見してくれている．若い薬剤師 や, 薬学部の学生であればその能力は大いに期待で きるのではないだろうか？ 日本は世界での高齢社 会のトップランナーである. 薬殽師のフロンティア はここにもあるようだ.

利益相反 開示すべき利益相反はない. 